Georgia State University

ScholarWorks @ Georgia State University

Counseling and Psychological Services Faculty Department of Counseling and Psychological

Publications

Services

2009

\title{
School Counselor Educators as Educational Leaders Promoting Systemic Change
}

\author{
H. George McMahon \\ University of Georgia, gmcmahon@uga.edu \\ Erin Mason \\ Georgia State University, emason15@gsu.edu \\ Pamela O. Paisley \\ University of Georgia
}

Follow this and additional works at: https://scholarworks.gsu.edu/cps_facpub

Part of the Counseling Psychology Commons

\section{Recommended Citation}

McMahon, H. G. \& Mason, E. C. M., Paisley. P.O. (2009). School counselor educators as educational leaders promoting systemic change. Professional School Counseling, 13(2), 116-124. doi:

http://dx.doi.org/10.5330/psc.n.2010-13.116

This Article is brought to you for free and open access by the Department of Counseling and Psychological Services at ScholarWorks @ Georgia State University. It has been accepted for inclusion in Counseling and Psychological Services Faculty Publications by an authorized administrator of ScholarWorks @ Georgia State University. For more information, please contact scholarworks@gsu.edu. 
H. George McMahon,

Ph.D., is an assistant professor at the

University of South

Alabama, Mobile.

E-mail:

gmcmahon@usouthal.edu

E. C. M. Mason, Ph.D., is

an assistant professor at

DePaul University,

Chicago

Pamela O. Paisley, Ed.D., is a professor at the

University of Georgia,

Athens.

\section{School Counselor Educators as Educational Leaders Promoting Systemic Change}

If the full impact of the transformation of the school counseling profession is to be enacted, it is incumbent upon school counselor educators to model the same skills and professional mindset that are expected of practicing school counselors. Specifically, school counselor educators can serve as leaders within their educational communities in order to promote systemic change that will remove barriers to student success. The notion of school counselor educators as educational leaders represents a philosophical and behavioral congruence that churns the professional ecosystem, from the professor to the practitioner to the P-12 student. This article outlines the role that school counselor educators can play in modeling leadership and other essential skills for the profession.

r his article is collaboration among the three authors on several levels. It should be noted that the three authors have a special bond: We represent a professional lineage. Specifically, Pamela Paisley served as George McMahon's major professor, who in turn served as Erin Mason's major professor. These relationships were not strictly hierarchical, however, as each of the three has influenced the other two in several ways. Although the idea for this article grew from discussions between the first two authors (McMahon and Mason) as they developed a master's-level class on leadership and advocacy, the authors were very aware that the ideas were inspired from the lessons and modeling of the third author (Paisley). As McMahon and Mason began to write, they realized they needed Paisley's voice to ground the article and provide a "lived experience" of the subject. What follows are the professional reflections of a true leader in the fields of school counseling and education, designated by italics, interwoven into the body of the article describing a vision of school counselor educator leadership, a vision that is grounded in the experience of our mentors and role models.

\section{CONSTRUCTING A "NEW VISION" OF PROFESSIONAL SCHOOL COUNSELING}

I was a school teacher for 3 years, a school counselor for 7 , and have been a counselor educator for 22 years. I am fascinated by the changes I have seen occur in the school counseling specialty, and I support the ongoing dialogue regarding school counselor role to improve educational experiences and outcomes for all children. As a principal investigator on one of the six Transforming School Counseling grants, I have had my beliefs challenged and had to confront the ways in which my own privilege shaped my views and my behaviors. I was involved in significant curricular and programmatic reform as part of this initiative. I continue exploring these challenges 10 years later, growing as a professional and as a person committed to principles of social justice. I always feel that I am "in the process of becoming” a social justice advocate and an educational leader.

School counseling has a long and proud history, and the story of professional school counseling, its influences, and major players are key components of the collective professional identity that unites all those within school counseling. Paisley and Borders (1995) described school counseling as continually evolving to meet the economic, educational, and political needs of the community. Like evolution elsewhere in nature (Capra, 1996), the evolution of professional school counseling seems to have been marked by dramatic shifts rather than slow, steady change. The turn of the century provided the latest of these dramatic shifts, when the profession came together in landmark efforts to articulate a unified philosophy and mission for professional school counseling (American School Counselor Association [ASCA], 2005, 2008). Through these efforts and ongoing professional dialogue, school counselors, counselor educators, and others intimately involved with school counseling have begun to revise the 
story of who we are as school counselors (Lewis \& Borunda, 2006).

This revised story, often referred to as the "new vision" of school counseling, depicts school counselors taking on leadership roles within the schools and working systemically to help all students succeed (DeVoss \& Andrews, 2006; House \& Hayes, 2002; House \& Martin, 1998). This new vision was first articulated by the Transforming School Counseling Initiative (TSCI; Education Trust, 1996; House \& Martin) and was further constructed through ongoing professional conversations (DeVoss \& Andrews; Paisley \& McMahon, 2001). This new vision was further articulated through the creation of the ASCA National Model ${ }^{\circledR}$ (2005), which applies "new" skills of leadership, collaboration, systemic change, advocacy, and use of data over the foundation of a comprehensive, developmental program. The result is a framework for an organized, systematic approach that utilizes a combination of direct and systemic services, making the most of a wide variety of counselor skills to help all students succeed.

As school counselor educators and practicing school counselors have wrestled with the new vision of school counseling and its implications for practice and preparation, Professional School Counseling, the flagship journal of ASCA, has been a consistent vehicle for pivotal discussions. By now, most Professional School Counseling readers are very familiar with the tenets of the Transforming School Counseling Initiative (Education Trust, 1996) and the ASCA National Model (2005). At its core, the TSCI was grounded in the belief that all children can learn and be successful in schools, and it called for school counselors to play a more essential role in schools by identifying and addressing systemic barriers to student learning. In addition, it was hypothesized that school counselors would need to use skills not traditionally associated with counseling programs in order to create the type of systemic change necessary. Among them were advocacy, collaboration, the use of data, and leadership skills (Education Trust; House \& Hayes, 2002). Although radical and quite controversial at the time, these "new" skills were adopted in large part by the ASCA National Model as "essential skills." Now taking center stage as the standard of school counselor preparation, these skills are included in the foundation of the latest edition of the Council for Accreditation of Counseling and Related Educational Programs (2009) standards for school counseling preparation programs and the recently released draft of ASCA's (2008) school counselor standards and competencies.

Since the initiation of the TSCI, advocacy and collaboration have become common topics throughout the school counseling literature, while articles concerning leadership in school counseling have remained far less common (Baker \& Gerler, 2008). Still, leadership is viewed as a critical (House \& Hayes, 2002; Paisley \& Hayes, 2003) if not the critical component in the new vision (Davis, 2005; DeVoss \& Andrews, 2006). In fact, leadership can be viewed as the foundation for the transformed school counselor. First, leadership is not simply a skill, but a "mindset" from which school counselors work (Stone \& Dahir, 2006). In this way, leadership assumes a professional stance that is a prerequisite for the employment of the other essential skills in the ASCA National Model. For example, acting as an advocate $i$ taking on a leadership role, and using data to identify marginalized or underserved student groups or collaborating with stakeholders and other educators in order to remove barriers to student success fall squarely into the realm of leadership.

Additionally, and perhaps most importantly, the assertion that school counselors become leaders within their schools is significant because, perhaps for the first time, it places school counselors directly in the field of education as well as counseling. In order for school counselors to become more effective leaders in their schools, it follows that they would incorporate "educator" into their professional identity alongside "counselor." Although there has been debate about whether the professional identity of school counselors should align more in counseling or in education, it is our belief that today's school counselors can embrace both identities simultaneously, so that they always serve as both counselors and educators (Paisley, Ziomek-Daigle, Getch, \& Bailey, 2006; Webber \& Mascari, 2006; Ziomek-Daigle, McMahon, \& Paisley, in press).

The initial focus of the TSCI was to change the way that school counselor educators prepared graduate students to meet the needs of public school students in the 21st century (DeVoss \& Andrews, 2006; Education Trust, 1997). Thus, it was school counselor educators who led the way initially, enacting many of the early changes. Initial programmatic changes ranged from curricular updates to incorporate the new skills, to the recruitment of prospective students who were more aligned with the "new vision," to changing the way courses were taught, and even to challenging preparation programs to develop collaborative working relationships with stakeholders in the community (Education Trust). Since the initial stages, however, the focus of transformation has shifted from school counselor preparation to school counseling practice. Professional school counselors have been asked to embrace this new vision, which not only demands that they expand their skills set and redefine the role they play in schools (Paisley \& Milsom, 2007), but to embrace a new philosophical position-indeed an updated professional identity - that may be very dif- 
ferent from the one taught in their own preparation programs.

In light of the apparent shift in focus from school counselor preparation to school counselor practice, there may be more work for school counselor educators to do in order to better prepare their students to practice in a way that is consistent with the new vision. Even with the myriad changes made in school counselor preparation programs, questions remain about the ability of school counselor education programs to adequately prepare their graduates to play the role that is demanded of them in schools (Kaffenberger, Murphy, \& Bemak, 2006). One concern is that the changes many school counselor educators have made to this point have been primarily curricular in nature (e.g., Pérusse, Goodnough, Donegan, \& Jones, 2004). This may not be sufficient, as the new vision is not simply about doing different things, but doing things differently. In order to fully internalize this new vision, it would likely benefit school counseling students to work with role models and mentors who approach their jobs from the same perspective. Simply stated, it would make sense that, in order to adequately prepare professional school counselors (PSCs) to work from the new vision, school counselor educators must embrace the new vision as well. To this point, however, school counselor educators (SCEs) as a whole have not been asked to make the same fundamental and profound changes in role and professional identity that practicing school counselors have.

Perhaps part of the reason that SCEs have not been asked to make such fundamental changes is that there remains some degree of separation between school counselor educators- "those who teach"-and professional school counselors - "those who do." This distance between practitioners and professors also serves to keep the transformation at a distance-something that "they" (practicing school counselors) do. Dissolving these lines so that PSCs and SCEs are viewed as colleagues within the same professional circle may help the transformation to progress. Were this to happen, SCEs would fully adopt the same mindset, skills, and leadership practices that they expect from students and graduates, and they would intentionally use that perspective to inform their work. This way, school counselor educators become inseparable from the larger group (all school counseling professionals) working together to address barriers to student success at all levels of the American school system.

This article represents a call for school counselor educators to become more intentional about transforming the way they approach their jobs so that their actions are more congruent with their teaching. Specifically, our hope is that school counselor educators see themselves as essential educational leaders, and they act in accordance with this mindset. Our belief is that school counselor educators working from this perspective will not only model the skills, actions, and professional identity for their students, but will have the capacity to transform the environments in which their graduates work. Furthermore, we are aware that many school counselor educators have already incorporated this mindset into their work, and they are working systemically at various levels to promote success for all students. What follows is a brief sketch of the school counselor educator working from a "new vision" mindset, with a leadership identity at its core. In addition, we highlight specific examples identifying what SCEs can do, and are already doing, to help fully transform the profession.

\section{School Counselor Educators as Educational Leaders}

We began our journey with the new vision principles articulated through the Education Trust. These principles represented a shift in the model of school counseling from my own master's degree in the 1970s, which was focused on the "three Cs" of counseling, consultation, and coordination, to an extension that focused not only on counseling and coordination but also on embracing educational leadership, advocacy, team building, and assessment. This shift required that we look not only at the school counselor role but also at counselor education. We knew we could not prepare new vision school counselors with traditional methodologies. I came to understand that I could not prepare school counselors to be educational leaders if I was not willing to risk being one. I could not and still cannot talk about being an advocate, a leader, or a team builder in a classroom and not demonstrate behaving in those ways in my community. Leadership requires me to live what I am requiring of my students.

Leadership has not been a traditional component of school counseling programs (Baker \& Gerler, 2008; DeVoss \& Andrews, 2006), and just as some practicing school counselors may not view themselves as "leaders" (DeVoss \& Andrews), many school counselor educators were not prepared to think of themselves that way either. Certainly, many SCEs have established themselves as leaders within school counseling, as evidenced by scholarly activities such as research, conference presentations, and running for office within the profession. However, in order to fulfill the new vision of school counseling, it is elemental that SCEs also view themselves as leaders beyond school counseling and into the larg- 
er field of education. This form of leadership is about preaching beyond the choir. For instance, it is probably safe to say that school counselor educators are underrepresented in professional organizations within education, such as the American Educational Research Association; publish infrequently in noncounseling educational journals; or seldom present at educational conferences. Being educational leaders, however, requires that school counselor educators assert their voices into important conversations that are ongoing in these venues.

For many school counselor educators, becoming a leader in education will mean re-examining their professional identities. As stated above, the authors' position is that school counselor educators view themselves as both counselors and educators simultaneously, while resisting the inclination to choose one or the other (Paisley et al., 2006; Webber \& Mascari, 2006; Ziomek-Daigle, McMahon, \& Paisley, in press). Instead, SCEs can allow their "counselor perspective" (e.g., a holistic, developmental, multicultural perspective) to inform their contributions to conversations with other educational leaders. A first step in SCEs embracing leadership in education might be becoming stronger leaders within colleges of education. Serving on college committees, participating in community-university partnerships, and even applying for administrative positions within colleges of education all provide opportunities for SCEs to include their perspective and remind other educational leaders of the important role that professional school counselors can play in educational reform. Furthermore, becoming a leader within a college of education provides access to important conversations regarding policy and educational reform. By participating in and contributing to meaningful educational policy discussions, SCEs will be able to remind policy makers and other educational leaders of the impact that promoting healthy development of students, creating and maintaining a school climate that promotes growth and exploration, and valuing individual and cultural differences can contribute to student success.

Finally, this leadership mindset should be apparent in the classroom as well, so that students not only hear their professors discussing the importance of leadership, but "see" their professors taking leadership roles within the college and the community. SCEs, by being continuously reflective and transparent about their own leadership mindset, can share with students concrete experiences, examples, and tools for developing one's leadership identity. In so doing, SCEs expose their professional identity development process and, consequently, encourage students to be self-reflective about their own process.

\section{School Counselor Educators Working Toward Systemic Change}

"Living leadership" means always looking for the big picture, the systemic issues. It means not staying in my comfort zone of only talking to counselors and counselor educators. I have to be willing to be involved at a larger level in the College of Education and in my community. I have to be invested in my local school systems and supports. Without a single child of my own, I bave to care about the educational experiences and outcomes for all children in a general sense of social justice, and I also have to be committed to the specific young people within my local district. I need to show up at College of Education meetings, at county and state school counseling gatherings, at school board meetings, and yes, I must pay attention to local, state, and national politics. I have to look at assessment data and recognize trends and issues within our own graduate program and also within our society-trends that I may not want to see. I must give voice to issues that cannot and should not be ignored. These are the exact processes that I am requiring of graduate students. Those student requirements will have no substance or credibility if I do not also model this idea of "living leadership” as a counselor educator.

One of the central tenets of the Transforming School Counseling Initiative was to encourage school counselors to be more effective agents of change within their school systems (Education Trust, 1997; House \& Hayes, 2002). The focus on systemic change was closely aligned with leadership, as it was through leadership practices that school counselors were expected to help stakeholders identify barriers to student success and define a vision in which all students can be successful. Focusing on systemic change marked a departure from the traditional view of school counselors as ancillary direct service providers to essential educators who utilized leadership skills to eliminate systemic barriers to student success and create a school in which all students were able to succeed (House \& Hayes; Paisley \& McMahon, 2001).

This view of school counselors as systemic change agents was consistent with the social justice movement, which had been gaining momentum within the counseling profession. It is also consistent with an ecological perspective, which posits that the only way for school counselors to promote real and sustainable change in student outcomes is to change the system. A complete review of the ecological perspective is beyond the scope of this article, but for the purposes of this discussion, working ecologically
This artide

represents a call for school counselor educators to become more intentional about transforming the way they approach their jobs so that their actions are more congruent with their teaching. 
means understanding that any individual or any group of individuals must be understood within the context of their environment, and that their environment is actually made up of several (eco)systems, or networks, nested within one another (Capra, 1996; Conyne \& Cook, 2004). Furthermore, there is a constant flow of energy and information among all of these systems, so that any disruption in any one area quickly affects all areas (Capra).

Working toward systemic change from an ecological perspective with a goal of social justice has become a central focus for the new vision of school counselors, but it has several implications for school counselor educators as well. For instance, rather than buying into classifications that specify the arenas in which we work, an ecological perspective demonstrates that all professionals intimately connected with school counseling are part of the same process. The implication, then, is a shared responsibility for the goals of the new vision of professional school counseling. Rather than being seen as "those who teach," SCEs are active participants within the professional school counseling system. As such, SCEs are virtually mandated to become more deliberate about thinking and acting systemically, on a micro-level (e.g., within their colleges), a meso-level (with district-level school counseling supervisors), and a macro-level (within education and/or government). Only through such systemic interventions can SCEs create sustainable change and help education move toward a more socially just system where all students can succeed.

Furthermore, by asking SCEs to move beyond their classrooms and computers in order to link their efforts with the larger movement toward quality education (just as SCEs have asked school counselors to get out of their counseling offices and become essential cogs in their schools), school counseling students would have the opportunity to witness their professors and mentors modeling the skills and mindset they themselves are expected to attain. School counseling students will see their professors as committed to professional school counseling, and committed to P-16 education, and not just to academia. Perhaps most importantly, school counseling students will more clearly understand their own professional identity as both counselor and educator because their professors enact such an identity before their eyes.

\section{SCHOOL COUNSELOR EDUCATORS AS EDUCATIONAL LEADERS IN ACTION}

School counselor educators have not traditionally been expected to be leaders outside of their field of expertise; therefore, conceptualizing leadership and systemic change as part of the job might be a diffi- cult alteration in perspective for many SCEs. Although changing an approach to a job can be anxiety-provoking, in this case it is fortunate that a model already exists for school counselor educators to follow-the same one that school counselor educators helped to create for practicing school counselors. In the following, we identify how SCEs may act as leaders to transform their practice by using the same skills described by the TSCI and the ASCA National Model-specifically, collaboration, advocacy, and use of data.

\section{Collaboration}

One way for SCEs to assert themselves as educational leaders is to utilize the collaboration and teaming skills that they already possess. Professional collaboration can take many forms, and one of the easiest is to reach out across disciplines and departments within colleges and universities. Offering to serve as a guest lecturer, or volunteering school counseling students to guest lecture, can be an easy way to inform both professors and students in other departments (e.g., teacher prep, educational leadership, school psychology) about the new vision of school counseling and what today's professional school counselors can do to facilitate student achievement. Likewise, SCEs can invite professors and/or students from those other departments to come and speak with school counseling students. This sharing of information not only is important so that future educators better understand the roles that each can play in helping P-12 students succeed, but it fosters a sense of camaraderie among graduate students and sets norms of open communication and professional collaboration.

Examples of this type of professional collaboration can be seen at the University of Puget Sound and Sam Houston State, where SCEs model this type of collaborative leadership by coordinating with their educational leadership colleagues. At both institutions, students in both the educational leadership and school counseling degree programs share coursework and class time, leading to intentional dialogue about the role each profession can play in school improvement (Kirchner \& Setchfield, 2001; Nichter \& Nelson, 2006). This type of collaboration is crucial in order to prepare future school counselors and administrators who understand and value each other's role, and who view professional collaboration as a standard aspect of work in schools.

In addition to reaching across disciplines within colleges of education, SCEs can reach out to the community to set up collaborative relationships with local school systems. Establishing collaborative working relationships with system-level administrators, particularly supervisors of school counseling and/or student services, not only provides an 
opportunity to educate system administrators about the new skills and abilities of today's graduates, but will allow system administrators the opportunity to express their perspective on what school counselors need to be able to do, each informing the other as all work toward a common goal.

Hayes, Paisley, Phelps, Pearson, and Salter (1997) presented an early model of intentional collaboration between PSCs and SCEs. In their example, school counselors from a district, school counseling students, and school counselor educators from one university formed a group designed to work collaboratively toward shared goals, so that both district school counseling programs and the school counseling preparation programs would benefit. The focus of that collaborative effort was primarily to build stronger school counseling programs, both within P-12 schools and graduate programs (Hayes et al.). Another collaborative group in the state of Georgia, this one consisting of school counselor educators, Department of Education representatives, and district supervisors of school counseling throughout the state, has been meeting for several years to build professional relationships in order to inform each other's professional practice. Through this collaboration, the group has clarified and refined practicum and internship practices from both university and district perspectives, provided professional development opportunities for participants, examined reporting measures for school counseling activities, and advocated for pro-school counseling policies with the state Professional Standards Commission.

Other examples of professional collaboration exist to improve the sharing of resources among SCEs and PSCs. The Center for Excellence in School Counseling and Leadership (CESCaL), developed by Dr. Trish Hatch at San Diego State University, is an example of a collaborative effort among SCEs, practitioners, and graduate students to provide the field with training and resources pertinent to school counseling (CESCaL, 2008). CESCaL has as its mission the goal of assisting school counselors, school administrators, district staff, graduate students, and counselor educators who are implementing counseling programs based on the ASCA National Model. Through the CESCaL Web site, members can access resources to help school counselors build guidance curricula and other targeted intervention plans, and they submit their plans for feedback provided by experts in the field. The Web site also serves as a warehouse for pre-post tests, data reports, needs assessments, calendars, and other vital resources developed and used by practicing school counselors, all of which can be downloaded directly from the Web site.

\section{Advocacy}

A key component of leadership is advocating for one's profession, and thus it is crucial that school counselor educators be deliberate in advocating for professional school counseling and professional school counselors. One way for SCEs to become more intentional and active advocates is to create a stronger presence within colleges of education by becoming more involved with college strategic plans and policies. Whether volunteering on college committees examining structural issues, course offerings, or innovative collaborative educational programs, school counselor educators can include themselves in such conversations so that school counselors are seen as vital elements within the college rather than ancillary programs. For SCEs working in research institutions, making sure that school counselor educators are included in large educational grants is another way to ensure that school counselors are recognized as educational leaders, and to help demonstrate to other educators how school counselor interventions can affect student learning outcomes.

In addition to advocating for school counseling within colleges, SCEs can use their position as "experts" to advocate with state government and the legislature. Collaborative relationships with state officials have a history of being mutually beneficial (Gysbers, 2006) but remain an underutilized resource for the advancement of professional school counseling. Recently, several examples of collaborative leadership groups developed to advocate for school counseling have emerged. One example of this type of group is the School Counseling Leadership Team (SCLT; Kaffenberger et al., 2006). The primary goal of the SCLT, whose members include district supervisors of school counseling and leaders of state school counseling organizations, has been to advocate for the new vision of professional school counseling at local, state, and regional levels (Kaffenberger et al.). In addition to several advocacy activities, the SCLT also helped in the development of a Virginia state model for school counseling programs.

In Georgia, where lobbying efforts were organized through the state professional organization including the Georgia School Counseling Association, SCEs (along with district supervisors) have volunteered on government relations committees and built relationships with lobbyists and lawmakers, particularly those involved with education committees. These types of lobbying efforts are important because most legislators are not educators, and few to none have counseling backgrounds. As a result of these efforts in Georgia, SCEs and district supervisors helped legislators with proper language within education bills (e.g., using "school counselor" instead of "guidance counselor") and helped them 
to understand the roles school counselors can (and cannot) play in educational reform legislation. These SCEs also took graduate students to the state capitol and brought in local lobbyists to further articulate the applications of the school counselor's advocacy role.

\section{Use of Data}

As researchers, many school counselor educators are collecting various forms of data regarding school counseling practices and school counseling intervention/programmatic outcomes, and recently there has been a renewed focus to collect such data (Carey \& Dimmitt, 2006; Sink, 2006). It is important to note, however, that the skill is not simply "collection of data," but "use of data." Therefore, the focus is not on what data is collected, but how that data is used. Traditionally, many SCEs have conducted such research with the goal of publishing in professional journals such as Professional School Counseling or Journal of Counseling \& Development (and, hopefully, to inform practice). Acting as educational leaders and systemic change agents, it becomes vital for SCEs to ensure that practicing school counselors have access to that data as well. Furthermore, it is a great opportunity for PSCs and SCEs to work collaboratively to collect outcome data.

There are several examples of collaborative leadership collecting and providing access to data in order to promote accountability of school counseling programs. Toward this end, the Center for School Counseling Outcome Research at the University of Massachusetts at Amherst (www.umass.edu/ schoolcounseling; Carey \& Dimmitt, 2006) is a resource founded by SCEs that is designed to promote data-based decision making among PSCs and make research supporting school counseling interventions easily accessible. The evidenced-based practices panel of the Center for School Counseling Outcome Research (CSCOR) has done extensive review of several school counseling interventions. CSCOR faculty and staff also have developed tools for generating, measuring, and analyzing data from school counseling programs in addition to producing significant research briefs and monographs.

The Center for Student Support Systems (CS3), located in the University of San Diego's School of Leadership and Education Sciences, is another such collaborative effort. With SCEs, students, and practicing school counselors contributing, CS3 has at the core of its mission to strengthen school counseling practice by promoting effective, data-driven comprehensive student support systems (Rowell, 2008; University of San Diego, 2008b). As an important part of CS3, Dr. Lonnie Rowell has developed an "Action Research Lab," an open resource for practitioners, students, and SCEs to share infor- mation and data related to school counseling programming and interventions (University of San Diego, 2008a).

As educational leaders, however, SCEs also ensure that school counseling outcome data are communicated to policy makers and other educational leaders for the purpose of systemic change and educational justice. SCEs have a responsibility to make sure that policy makers at the district, state, and national levels are included in the process of using outcome data, for example, to recognize the contributions of school counseling programs. An advisory group of Los Angeles County counselors, counselor supervisors, counselor educators, and California Department of Education consultants developed the Support Personnel Accountability Report Card (SPARC; Los Angeles County Office of Education, 2008) to showcase and recognize the combined work of local school support teams including school psychologists, school social workers, nurses, school counselors, and other educators. The SPARC recognition program in California publishes local school data in the form of "report cards," highlighting the shared efforts of a variety of educators including school counselors.

One area that is not as well documented is the practice of SCEs using data to evaluate their own preparation program's outcomes. Just as SCEs can help PSCs to effectively use data, SCEs also can use data as a tool to determine the effectiveness of their programs - specifically, whether the graduates are able to promote academic achievement and school success among their students. It is important that SCEs see this type of accountability as an opportunity, rather than something imposed upon them. As Gysbers (2004) stated, accountability is best viewed as a way to demonstrate how we are effective and where we can improve, rather than as a threat to our position. Regarding school counselor preparation programs, this translates into embracing the opportunity to collect and analyze data to determine whether, and how, school counselor educators are succeeding in their attempts to prepare school counselors to improve student success and close achievement/opportunity gaps in their schools. Such a practice will allow SCEs to demonstrate the effectiveness of their programs, while also adding to the collection of data supporting the use of school counselors to improve student success.

Alternatively, if data collected do not indicate that graduates are having a positive effect on student achievement, it provides SCEs the opportunity to investigate barriers to their graduates' ability to help their students. Whether these barriers are related to preparation, performance, systemic conditions, or all of the above, embracing accountability would provide SCEs with important information to guide 
ongoing leadership and systemic change, whether working within their graduate programs or the school systems. This is also consistent from an ecological perspective in that it provides a clear link among those within the school counseling profession, that whatever role we play, we are linked toward the same goal: success for all students.

\section{CONCLUSION}

I have long ago understood what I referred to earlier - I am a "work in progress." I am on a journey related to multiculturalism, social justice, advocacy, and educational leadership. I will definitely make mistakes and missteps. I acknowledge that my own privilege is something I cannot "get over"; I can only "get on with $i t$ " confronting myself about the ways in which that privilege blinds me to the inappropriateness of some of my perspectives and behaviors. What I am committed to is staying in the conversation, continuing on the journey, and owning my responsibility to model the leadership I would like my graduate students and practicing school counselors to embrace.

Since its introduction, the ASCA National Model has changed the way that many professional school counselors conceptualize their role (Pérusse et al., 2004) and the way they perform their jobs in schools (Walsh, Barrett, \& DePaul, 2007). Although school counselor educators have been intimately involved in this transformation process in terms of reconstructing goals and practices of school counselor preparation (Education Trust, 1997; House \& Hayes, 2002), SCEs have not been asked to transform their vision and practice in the same way practicing school counselors have. By intentionally incorporating "new vision" skills and mindset into their own professional work, school counselor educators can contribute to the ongoing transformation of school counseling. Specifically, by becoming educational leaders and systemic change agents themselves, SCEs can promote "new vision" school counseling through facilitating change in the larger school systems while simultaneously modeling crucial skills and professional mindsets for their students.

Practicing school counselors across the United States are responding to a call for them to transform the way they approach their jobs, collaborating with other stakeholders, advocating for systemic change, and taking on the mindset of an educational leader in order to help all students succeed. In order for this transformation to have full effect, school counselor educators need to answer the same call and adopt these same principles and approaches to their work. By taking an ecological perspective, SCEs understand that they are integral components of the school counseling profession and education, and that their professional actions and goals should be aligned with those in their extended network. By utilizing the same skills and, most importantly, taking on the mindset of essential educational leader, school counselor educators can advocate for systemic change and for enabling professional school counselors to put their unique talents to work in P12 schools.

\section{References}

American School Counselor Association. (2005). The ASCA national model: A framework for school counseling programs (2nd ed.). Alexandria, VA: Author.

American School Counselor Association. (2008). School counselor competencies. Retrieved September 28, 2008, from http://www.schoolcounselor.org/files/ SCCompetencies.pdf

Baker, S. B., \& Gerler, E. R. (2008). School counseling for the twenty-first century (5th ed.). Upper Saddle River, NJ: Pearson Merrill/Prentice Hall.

Capra, F. (1996). The web of life: A new scientific understanding of living systems. New York: Doubleday.

Carey, J. C., \& Dimmitt, C. (2006). Resources for school counselors and counselor educators: The Center for School Counseling Outcome Research. Professional School Counseling, 9, 416-420.

Center for Excellence in School Counseling and Leadership. (2008). Home page. Retrieved December 8, 2008, from http://www.cescal.org

Conyne, R. K., \& Cook, E. P. (2004). Ecological counseling: An innovative approach to conceptualizing personenvironment interaction. Alexandria, VA: American Counseling Association.

Council for Accreditation of Counseling and Related Educational Programs. (2009). CACREP standards. Alexandria, VA: Author.

Davis, T. (2005). Exploring school counseling: Professional practices and perspectives. Boston: Lahaska Press.

DeVoss, J. A., \& Andrews, M. F. (2006). School counselors as educational leaders. Boston: Lahaska Press.

Education Trust. (1996). National initiative to transform school counseling [Brochure]. Washington, DC: Author.

Education Trust. (1997). The national guidance and counseling reform program. Washington, DC: Author.

Gysbers, N. C. (2004). Comprehensive guidance and counseling programs: The evolution of accountability. Professional School Counseling, 8, 1-14.

Gysbers, N.C. (2006). Improving school guidance and counseling practices through effective and sustained state leadership. Professional School Counseling, 9, 245-247.

Hayes, R. L., Paisley, P. O., Phelps, R. E., Pearson, G., \& Salter, R. (1997). Integrating theory and practice: Counselor educator-school counselor collaborative. Professional School Counseling, 1, 9-13.

House, R. M., \& Hayes, R. L. (2002). School counselors becoming key players in school reform. Professional School Counseling, 5, 249-256.

House, R. M., \& Martin, P. J. (1998). Advocating for better futures for all students: A new vision for school counselors. Education, 119, 284-291.

Kaffenberger, C. J., Murphy, S., \& Bemak, F. (2006). Professional School Counseling, 9, 288-294. 
Kirchner, G. L., \& Setchfield, M. S. (2001). School counselors' and school principals' perceptions of the school counselor's role. Education, 126, 10-16.

Lewis, R. E., \& Borunda, R. (2006). Lived stories: Participatory leadership in school counseling. Journal of Counseling \& Development, 84, 406-413.

Los Angeles County Office of Education. (2008). Support Personnel Accountability Report Card. Retrieved December 8, 2008, from http://www.sparconline.net/ index.html

Nichter, M., \& Nelson, J. (2006). Educating administrators. ASCA School Counselor, 44, 14-20.

Paisley, P. O., \& Borders, L. D. (1995). School counseling: An evolving specialty. Journal of Counseling \& Development, $74,150-153$.

Paisley, P. O., \& Hayes, R. L. (2003). School counseling in the academic domain: Transformations in preparation and practice. Professional School Counseling, 6, 198-205.

Paisley, P. O., \& McMahon, H. G. (2001). School counseling for the 21 st century: Challenges and opportunities. Professional School Counseling, 5, 106-115.

Paisley, P. O., \& Milsom, A. (2007). Group work as an essential contribution to transforming school counseling. Journal for Specialists in Group Work, 32, 19-30.

Paisley, P. O., Ziomek-Daigle, J., Getch, Y. Q., \& Bailey, D. F. (2006). Using state standards to develop professional school counsellor identity as both counsellors and educators. Guidance \& Counselling, 21, 143-151.

Pérusse, R., Goodnough, G. E., Donegan, J., \& Jones, C. (2004). Perceptions of school counselors and school principals about the National Standards for School Counseling Programs and the Transforming School Counseling Initiative. Professional School Counseling, 7, 152-161.
Rowell, L. L. (2008, October). Action research: New perspectives on research and practice. Paper presented at the conference of the Southern Association of Counselor Education and Supervision, Houston, TX.

Sink, C. A. (2006). Introductory comments. Professional School Counseling, 9, 336.

Stone, C. B., \& Dahir, C. A. (2006). The transformed school counselor. Boston: Lahaska Press.

University of San Diego. (2008a). Action research lab. Retrieved December 12, 2008, from the University of San Diego School of Leadership and Educational Sciences Web site: http://www.sandiego.edu/soles/centers/student_ support_systems/projects/action_research_lab.php

University of San Diego. (2008b). Center for Student Support Systems. Retrieved December 12, 2008, from the University of San Diego School of Leadership and Educational Sciences Web site: http://www.sandiego. edu/soles/centers/\#center_for_student_support_systems

Walsh, M. E., Barrett, J. G., \& DePaul, J. (2007). Day-to-day activities of school counselors: Alignment with new directions in the field and the ASCA National Model ${ }^{\circledR}$. Professional School Counseling, 10, 370-378.

Webber, J. M., \& Mascari, J. B. (2006). Counselor or educators: Strengthening the professional identity of school counselors. ACA VISTAS Online.

Ziomek-Daigle, J., McMahon, H. G., \& Paisley, P. O. (in press). Adlerian-based interventions for professional school counselors serving as both counselors and educational leaders. Journal of Individual Psychology.

Earn CEUs for reading this article. Visit www.schoolcounselor.org, and click on Professional School Counseling to learn how. 